\title{
THE EMERGENCE AND PERSISTENCE OF RACIALISED STEREOTYPES ON DUTCH TELEVISION
}

\section{TRACING THE HISTORY OF REPRESENTATION OF MUSLIM IMMIGRANTS ALONG THE ARCHIVAL GRAIN}

\author{
Andrea Meuzelaar \\ Utrecht University \\ a.meuzelaar@uu.nl
}

\begin{abstract}
Today, stereotypical and racialised imaginations of Muslims are pervasive on Dutch television. This article traces the history of Dutch television coverage of Muslim immigrants through the lens of the archive of Sound and Vision. It demonstrates that during their symbolic transformation from 'guest workers' to 'ethnic minorities' to 'allochtonen' and 'Muslims', television's visual repertoire of Muslim immigrants has become increasingly racially inscribed. Finally, it argues that the archive of Sound and Vision has played a performative role in the emergence and persistence of racialised stock stereotypes of Muslim immigrants.
\end{abstract}

Keywords: Muslim immigrants, racialised visual repertoires, stock stereotypes, Institute of Sound and Vision, Dutch television history, television historiography

\section{Introduction}

Today in the Netherlands, like elsewhere in Europe and beyond, public discourse on immigration and multiculturalism is often conflated with Islam while symbolic violence against Muslim minorities has risen to epidemic proportions. In their edited volume Dutch Racism, Essed and Hoving state that in the wake of 9/11 "gendered and racially inscribed imaginations of 'the Muslim' or 'the veiled' woman became one of the most visible forms of racism." Obviously, television plays a key role in the perpetuation of these racially inscribed imaginations of Dutch Muslims; not only does television reproduce racialised portrayals of Dutch Muslims through the stories it tells, but also through the visual repertoire it uses to illustrate these stories. Stereotypical images, such as veiled Muslim women at the market and praying Muslims, circulate daily on Dutch television and illustrate all sorts of stories about immigration, multiculturalism, integration and even terrorism. While the negative and even racist connotations of this kind of imagery might have become rather visible today, these connotations haven't appeared out of thin air but have emerged through the process of constant repetition. This raises the question of how and when did television's visual repertoire of Muslim immigrants become racially inscribed? How did television visualise stories about Muslim immigrants in the past? And how did today's rigid and racialised iconography of Muslims emerge? 
In this article I delve into Dutch television's past and trace the history of television coverage of Muslim immigrants through the lens of the archiving practices of the Institute of Sound and Vision. Ever since the arrival of Turkish and Moroccan workers in the early 1960s, Dutch television has covered stories and produced an enormous amount of images of Muslim immigrants. These stories and images have been preserved by the archive of Sound and Vision, where they have been catalogued and made available for reuse through keywords and descriptions. In this article I demonstrate that the characteristics that both Dutch television and the archive of Sound and Vision has assigned to the typical Muslim immigrant have regularly changed and that over the course of time Turkish and Moroccan 'guest workers' have symbolically transformed into 'ethnic minorities,' 'allochtonen'2 and finally 'Muslims.' I identify four discursive formations and I present an analysis of the thematic patterns and the visual repertoires of television coverage of Muslim immigrants in each discursive formation. I depart from the idea that Sound and Vision's archival descriptions not only reflect television's changing discourses of Muslim immigrants, but also perpetuate the circulation of generic images of Muslim immigrants by repeating stock shots and catering to television's compelling need to visualise abstract stories. Therefore, I also analyse what stock shots the archive has earmarked for reuse in new contexts. I demonstrate that, while both television and the archive of Sound and Vision have always evaded explicit reference to 'race' in their stories and descriptions, the visual repertoire of Muslim immigrants went through a discernible process of racialisation. Finally, I argue that the archival descriptions have constantly reiterated this process of racialisation and have played a performative role in the emergence and persistence of television's racially inscribed visual repertoire.

Despite an increasingly significant body of academic work on Western media coverage of Islam with a particular focus on stereotypical depictions, ${ }^{3}$ hardly any research has been done on media coverage of Muslim immigrants in the Netherlands. ${ }^{4}$ This analysis of Dutch television's emergence and persistence of racialised visual repertoires of Muslim immigrants adds a further element to the existing literature, that is distinctive in both the ground it covers and in the methodological paradigm it brings to television historiography. This study aims to demonstrate that any understanding of contemporary racialised media imaginations of Muslim immigrants requires a sense of their historical emergence and development. Furthermore, by bringing the conceptual and methodological parameters of the archive to the study of television history, this study aims to contribute to a better understanding of the cultural dynamics of the circulation of visual stereotypes.

In the following sections I first elaborate on the theoretical notions of racialisation and stereotypes that inform this research, before briefly sketching the conceptual parameters of the archive that I bring to the study of television history and provide more information about the method that I have used to map the history of television coverage of Muslim immigrants. I then present an analysis of the visual repertoires and the archival descriptions in the various discursive formations. Finally, I demonstrate how racialised stock stereotypes of Muslim immigrants have emerged through a process of reiteration and I argue that the archive of Sound and Vision has been an autonomous actor in this process.

\section{Conceptualising Racialisation and Stereotypes}

Despite the fact that racialisation is a rather contested concept, I find it useful to analyse how television's visual repertoire of Muslim immigrants has become racially inscribed and to discuss newer forms of racism that are not only based on skin colour. ${ }^{5}$ Various scholars have made the argument that, in the context of European post-Holocaust sensitivities, new forms of racism have emerged that have recoded essentialist ideas about racial difference into other categories of difference, such as culture, ethnicity and religion. ${ }^{6}$ In this article, I want to adopt Omi and Winant's classical definition of racialisation as "the extension of racial meaning to a previously racially unclassified relationship, social practice, or group"7 and add the understanding that in the European post-war context ethnicity, culture and religion have come to act as - in Kenan Malik's phrasing - homologues of race. ${ }^{8}$ Also, I take my cue from Etienne Balibar's argument that "new racism" is a "racism without race", that presents the need to "purify the social body, to preserve 'one's own' or 'our identity from all forms of mixing, interbreeding or invasion" and that inscribes itself in representations that are "articulated around stigmata of otherness (name, skin colour, religious practices)." Finally, 
I turn to Garner and Selod's work on racialisation and Islamophobia which argues that racialisation is the "outcome of a process" that "entails ascribing sets of characteristics viewed as inherent to members of a group because of their physical and cultural traits." ${ }^{10}$ Racialisation, I argue, is the effect of a historical process that homogenises all members of a group on the basis of their physical and cultural traits (such as skin colour, language, clothing, and religious practices) and that draws a line between 'us' and 'them.'

Furthermore, this research builds on a paradigm for understanding stereotypes that rejects the notion of the stereotype as a misrepresentation of a given reality and instead considers stereotypes as forms of representation that are systematically implicated in repetition. Firstly, I find Homi Bhabha's notion of the stereotype as a "fetishistic mode of representation" that simultaneously articulates fear of and desire for the other helpful to understand both television's and the archive's compulsive repetition of "the same old stories" of Muslim immigrants (or in this case, the same old images). ${ }^{11}$ Rey Chow and Mireille Rosello help to further conceptualise and comprehend the repetitive nature of stereotypes. ${ }^{12}$ Chow returns to the original coinage of the word stereotype - that refers to the mould that was used in mass printing to duplicate pages and Walter Lippmann's notion of "pictures in our heads" - and characterises stereotypes as: "forms of representing (human beings) that involve, as in the case of printing, a deliberate process of duplication." ${ }^{3}$ Thereby Chow also underlines the fundamental visuality of stereotypes. Similarly, Rosello directs attention to the formal structure of stereotypes, to their high degree of what she has coined "iterativity": the memorability, quotability and timelessness of stereotypes. ${ }^{14}$ Rosello maintains that stereotyping practices are both the cause and the effect of an alliance between time and memory that develops into a vicious circle: stereotypes are successful because they are memorable, and their memorability is directly linked to their timelessness, which in turn increases their quotability and memorability. ${ }^{15}$ Chow's notion of the stereotype as a form of representational duplication and Rosello's concept of iterativity are useful to understand how certain generic images of Muslim immigrants have become racially inscribed through a process of repetition and to draw my attention to the media mechanisms that underlie this process.

\section{Reading the Archive along the Grain}

Theoretically, this article draws on a constructivist paradigm of archives, in which the archive is conceptualised as a spokesman of the language of discursive formations, as a monument to configurations of power, as a site of knowledge production, and as a place where cultural memory is manufactured. ${ }^{16}$ In particular, I build on Michel Foucault's notion of the archive as "the set of rules which at a given period and for a given society define the limits and forms of the sayable" and on his archaeological method for the analysis of discourse. ${ }^{17}$ Archaeology is in Foucault's definition concerned with discovering discontinuities in the archive's manifest appearance of discourses and with describing historically variable discursive formations - organized systems of statements that produce meaning relationally and acquire a unity throughout time.${ }^{18}$ Ann Laura Stoler, who is directly influenced by Foucault promotes a reading of the archive that also focuses on archival forms and practices. ${ }^{19}$ Stoler suggests reading the archive "along the archival grain" and to identity "the conditions of possibility which shaped what could be written, what warranted repetition [...]." ${ }^{20}$ She furthermore argues that "[...] to understand an archive, one needs to understand the institutions that it served. One needs to understand [...] what quotes are cited [...]." ${ }^{21}$ For Jacques Derrida, conceptualizing the archive is not "a question of the past" but "a token of the future," an anticipation of the future. ${ }^{22}$

Since Sound and Vision's mission is not only to preserve television heritage, but also to facilitate the reuse of its holdings for the various Dutch broadcasting organisations, I consider the archival metadata that Sound and Vision has used to disclose its collection not only as reflections of various discursive formations on Muslim immigrants, but also as acts that anticipate future use. ${ }^{23}$ For the broadcasters, the archive is primarily a collection of stock footage and therefore Sound and Vision uses a shot-based catalogue, in which certain non-specific images ("shots") have been highlighted as having a potential for reuse. ${ }^{24}$ Thereby the archive extracts these images from their original semantic context and places them - in Tom Nesmith's apt phrasing - on a "pedestal" to be cited in new contexts. ${ }^{25}$ In order to understand how television's visual repertoire of Muslim immigrants has emerged and evolved, it is crucial to analyse the archival descriptions that are involved in television's continuous dissemination of generic, racialised, and stereotypical imagery of Muslim immigrants. Although Sound and Vision has not documented how their archival material is reused, it can be 
construed that the highlighting of stock shots to facilitate television journalists in their quest for readily available images has a performative dimension that feeds into the persistence of a rigid visual repertoire of Muslim immigrants. ${ }^{26}$ I argue following Chow's and Rosello's conceptualisation of stereotypes - that the generic stock shots of Muslim immigrants that the archive of Sound and Vision has highlighted are explicitly designed for duplication and consequently enhance the iterativity (the quotability, memorability and timelessness) of racialised visual stereotypes of Muslim immigrants.

In line with the Foucauldian method of archaeology and Stoler's recommendation to read the archive along the grain, I have taken the (former) iMMix catalogue of Sound and Vision as the starting point of my research and I have let the metadata that Sound and Vision has used to disclose its collection guide me through television history. ${ }^{27}$ My research covers the period from 1960 to 2010, and traces the keywords "Muslims" and "Islam" through the archive. First of all I have indicated the total amount of programmes/items about the Dutch context that these keyword rendered in each decade. ${ }^{28}$ Since the iMMix catalogue specifies which additional keywords the material has received, I have also investigated how the keywords of "Muslims" and "Islam" were interrelated with other key words, such as "foreign workers" (buitenlandse werknemers) and "ethnic minorities"(etnische minderheden). For each decade, I have identified the thematic patterns and the visual repertoire of the television coverage of Muslim immigrants and I have investigated what generic stock shots have been selected for reuse by the archival descriptions. ${ }^{29}$ Finally, I have identified four discursive formations, based on the historical moments during which the dominant keywords to label programmes about Muslim immigrants, the language that television used to talk about Muslim immigrants, and the thematic patterns of television coverage began to shift. ${ }^{30}$

\section{The Sixties and Seventies: The Discursive Formation of the Single Male Guest Worker}

As is true for several other European countries, the arrival of Muslims in the Netherlands was mostly the result of large-scale labour immigration. ${ }^{31}$ Since the early sixties, post-war reconstruction efforts and economic growth had led to shortages of low-skilled workers in various sectors of the Dutch industry and companies started to employ "guest workers" from Southern European countries and later from Turkey and Morocco. During the first two decades of labour immigration, the attitude of the Dutch government was determined by the idea that labour immigration would be temporary. The government did not implement any immigration policy and favoured the term "guest workers" over "immigrants" to stress the temporality of their stay. ${ }^{32}$
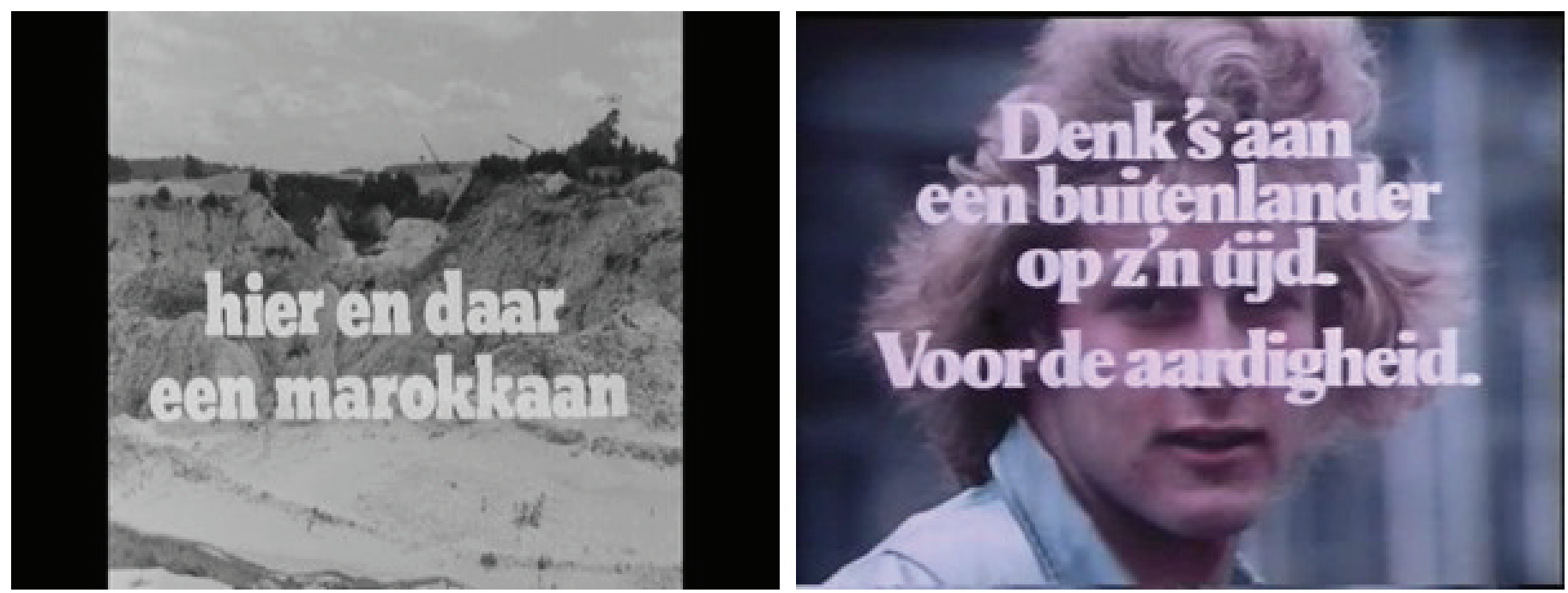

Figure 1. Still from the titles of Hier en Daar een Marokkaan (Here and There a Moroccan) (RKK, 29-12-1970) and from an infomercial to promote understanding for foreigners (Postbus 51, RVD, 01-01-1975). 
In this discursive formation, the bulk of television programmes that featured Turkish and Moroccan labour immigrants addressed their harsh socio-economic conditions and were labelled by Sound and Vision with the keyword "foreign workers" (buitenlandse werknemers). ${ }^{33}$ The predominant themes that ran through television coverage were their miserable housing conditions, their exploitation by Dutch employers, the (helpful and reluctant) attitude of the Dutch, their struggle for emancipation, and their illegalisation. ${ }^{34}$

The tone of the coverage was often engaged and many programmes advocated tolerance and critiqued the myth of Dutch hospitality. Programmes such as Hier en Daar een Marokkaan (Here and There a Moroccan) and Postbus 51 public service announcements were exemplary for the climate in these years, in which the guest worker - male, separated from his family and struggling for his emancipation - was mainly spoken of as a working-class foreigner who should be approached with tolerance (see figure 1). ${ }^{35}$
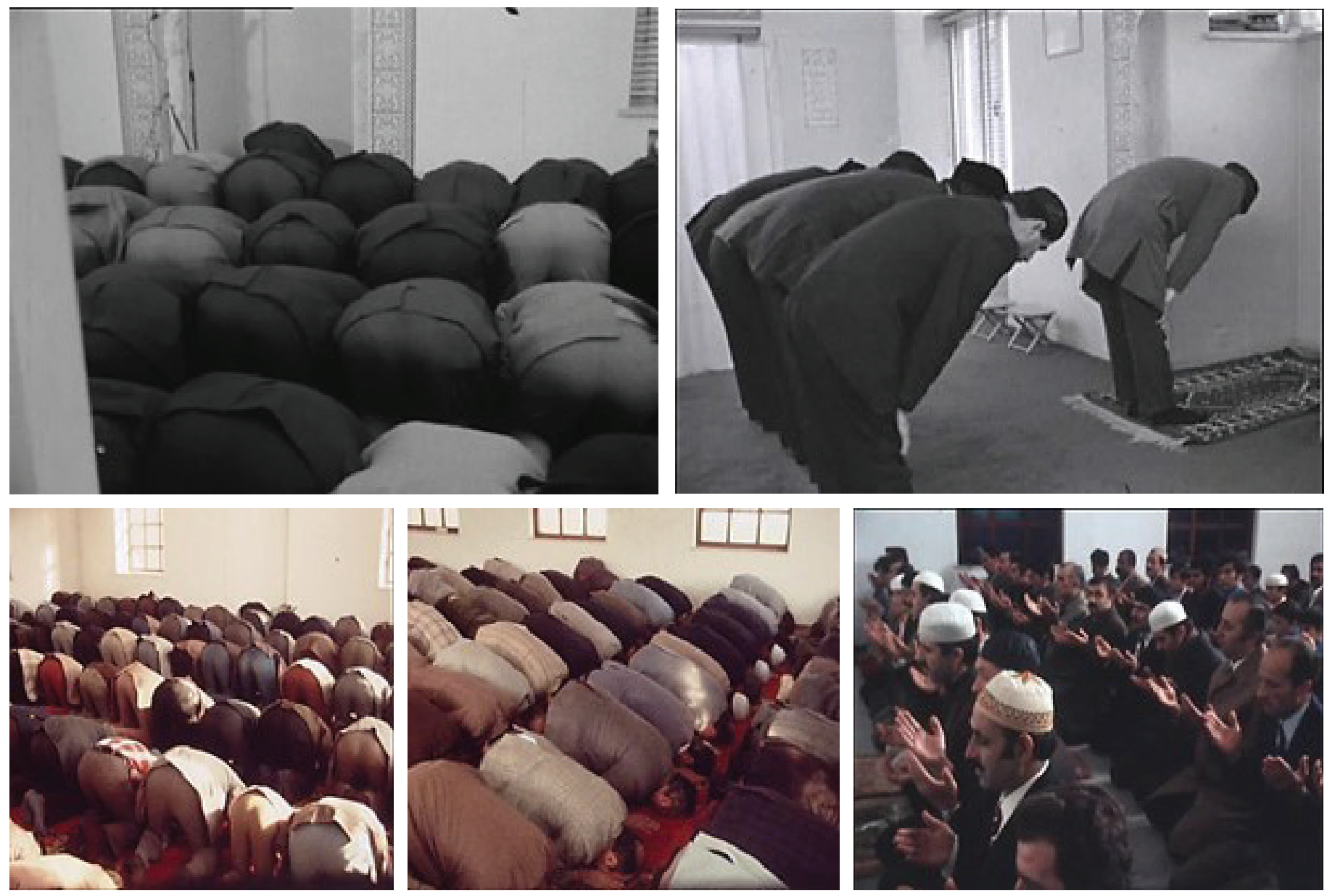

Figure 2. A selection from stills from Journaal (NOS, 01-01-1968) (a), Zienswijze (NOS, 23-11-1969) (b), Van Gewest tot Gewest (NOS, 06-11-1974) (c, d) and Journaal (NOS, 17-10-1974).

In these initial years, television only sporadically addressed the religious identity of the Turkish and Moroccan immigrants. The coverage that did revolve around their religious identity (and that was additionally labelled with the keyword "Muslims" or "Islam") was limited to stories about the nature of their religious rituals and celebrations, the lack of facilities to practice their faith, their struggle for emancipation in the religious sphere and the opening of the first mosques. ${ }^{36}$ The recurrent visual motifs were men performing communal prayers, men reciting the Quran, close-ups of men kneeling and bending to the ground while proclaiming "Allahu Akbar," exteriors and interiors of mosques, and close-ups of Arabic writing (see figure 2). Television's gaze displayed a fascination for the unfamiliar, 
exotic performance of the unfamiliar rituals of Islam, exhibiting a sense of curiosity towards the nature of Islam and stressing its otherness (see figure 3 for more examples). ${ }^{37}$
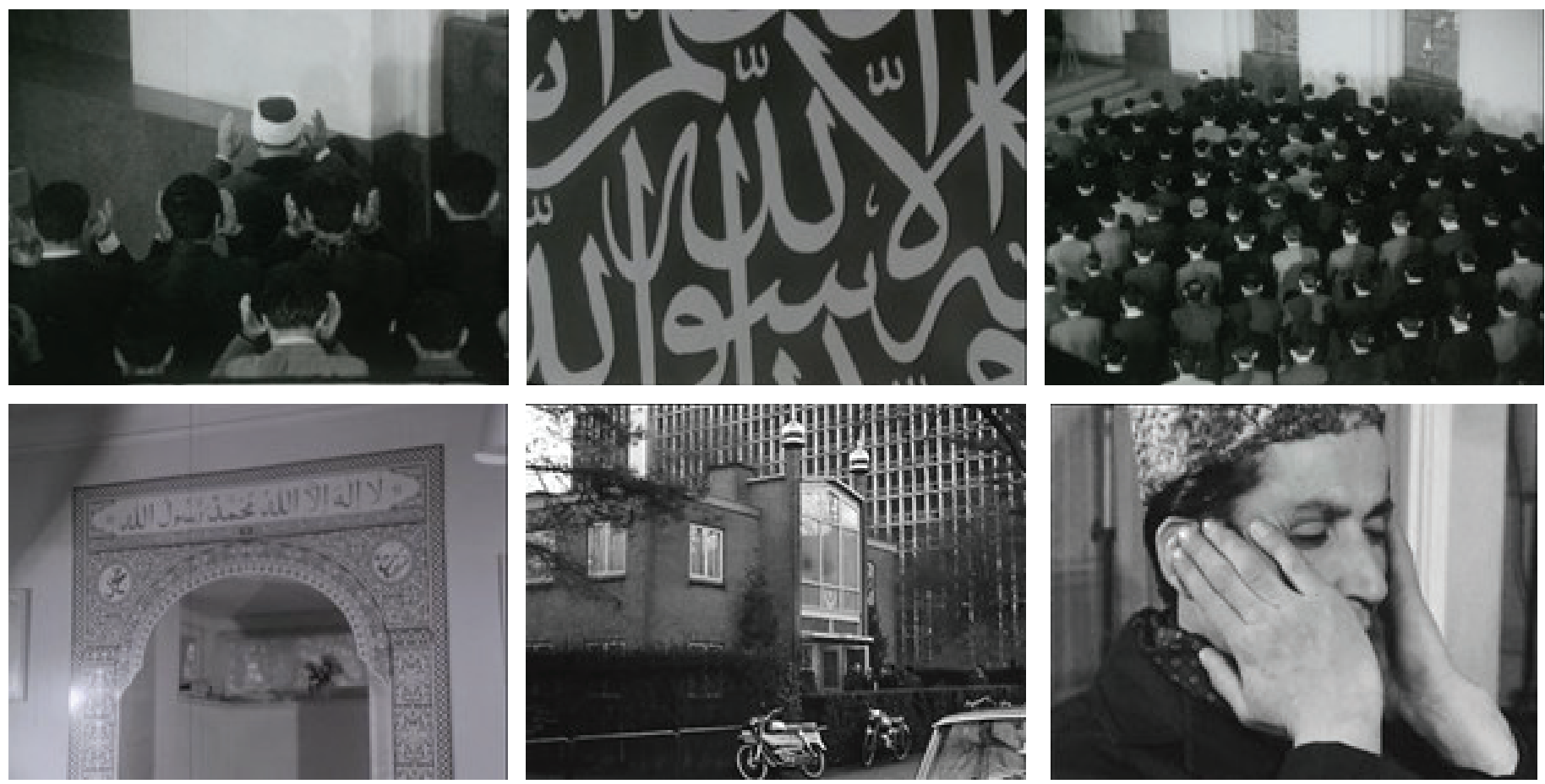

Figure 3. A selection of stills from Attentie (NCRV, 11-02-1966) (a, b, c, d), Journaal (NOS, 01-01-1968) (e), and Televizier (AVRO, 25-03-1965) (f).

Remarkably, the archival descriptions of this coverage reiterated television's fascination for the rituals and externals of the Islamic religion. Sound and Vision has persistently earmarked the above described imagery as stock shots for reuse. The archival descriptions have mentioned for example: "a praying Muslim,"38 "prayers in a mosque,"39 "communal prayer," 40 "Muslims praying on the knees and bending to the ground," 41 "a mosque in the Netherlands," 42 "exterior and interior of mosque," 43 "announcement by muezzin from minaret" 44 (see figure 4 for examples).

Apparently, Sound and Vision shared television's interest in the Muslim's prayer and place of worship and valued this imagery as reusable in new contexts. Sound and Vision also highlighted stock shots of mosques and prayers in descriptions of programmes that did not explicitly address the religious identity of the Turkish and Moroccan immigrants. These programmes revolved around other aspects of their lives and never mentioned their religion, but did include some images of a mosque and/or prayer. Strikingly, exactly these images were highlighted by the archival descriptions (and consequently the programmes were tagged with the keyword "Islam"). ${ }^{45}$ So Sound and Vision's interest in imagery of mosques and prayers did not always arise from the thematic structure of the programmes on the guest-worker and took on an autonomous dimension. 


\begin{tabular}{|c|c|}
\hline Selection type & item \\
\hline ID & LTI185679_POS91027779 \\
\hline Title & KENMERK \\
\hline Length & $0: 00: 00$ \\
\hline \multirow[t]{4}{*}{ Long Summary } & 1. Islamitisch vasten. \\
\hline & - Biddende Islamiet $10^{\prime \prime}+45^{\prime \prime}$ \\
\hline & Fxt. Mobarak moskee in Den Haag 21" \\
\hline & - Interview van Joop Reinboud met Imam \\
\hline \multirow[t]{2}{*}{ Subject terms } & Name \\
\hline & islam \\
\hline \multirow[t]{3}{*}{ Geographical names } & Name \\
\hline & Nederland \\
\hline & Den Haag \\
\hline \multirow[t]{3}{*}{ Corporations } & Name \\
\hline & ramadan \\
\hline & Mubarak-moskee \\
\hline \multicolumn{2}{|l|}{ IES: 'T ZAND 33 () } \\
\hline \multicolumn{2}{|l|}{ RAMADAN } \\
\hline \multicolumn{2}{|c|}{$\begin{array}{l}\text { igitale dragers: } 2 \text { x MXF | 2x DPX । 2x WAV } \\
\text { naloge dragers: - }\end{array}$} \\
\hline \multicolumn{2}{|c|}{$\begin{array}{l}\text { Shots Otman Akkurt, Turk en moslim, oa bij zijn werk bij de } \\
\text { IS } 130^{\prime \prime}+51^{\prime \prime}+\text { bij gebeden thuis } 111^{\prime \prime}+\text { bij gezamenlijke }\end{array}$} \\
\hline \multicolumn{2}{|l|}{$\begin{array}{l}\text { eest thuis met famili } \\
25^{\prime \prime}\end{array}$} \\
\hline \multicolumn{2}{|c|}{$\begin{array}{l}\text { 2. Interview Maria ter Steeg met mevr. Dutrieux, die ijvert } \\
\text { voor eigen gebedsruimte voor moslim in Amersfoort (A film). } \\
5^{\prime} 03^{n}\end{array}$} \\
\hline
\end{tabular}

Figure 4. Descriptions of stock shots from Kenmerk (IKOR, 16-01-1967) ("A praying Muslim" and "Ext. Mobarak mosque in The Hague") and 'T Zand (RKK, 14-06-1979) ("prayers at home," "communal prayer" and "praying Muslims").

\section{The Eighties: The Discursive Formation of Ethnic Minorities and the Permanent Settlement of Muslims}

In the beginning of the eighties, the Dutch government abandoned the symbolism of the immigrant as guest, recognised that the Turkish and Moroccan immigrants were in the country here to stay, and finally, in 1983, implemented a national immigration policy ("minority policy") with the formula: "integration with the preservation of cultural identity." 46 This policy was aimed at fighting the deprivation of minorities and at promoting tolerant pluralism. 
The period was marked by severe economic depression and mass unemployment, while the immigration from Turkey and Morocco kept rising as a result of family reunification and marriage immigration. ${ }^{47}$ The "guest workers" became "ethnic minorities" permanently settled in the Netherlands while Islam was gradually institutionalised. ${ }^{48}$
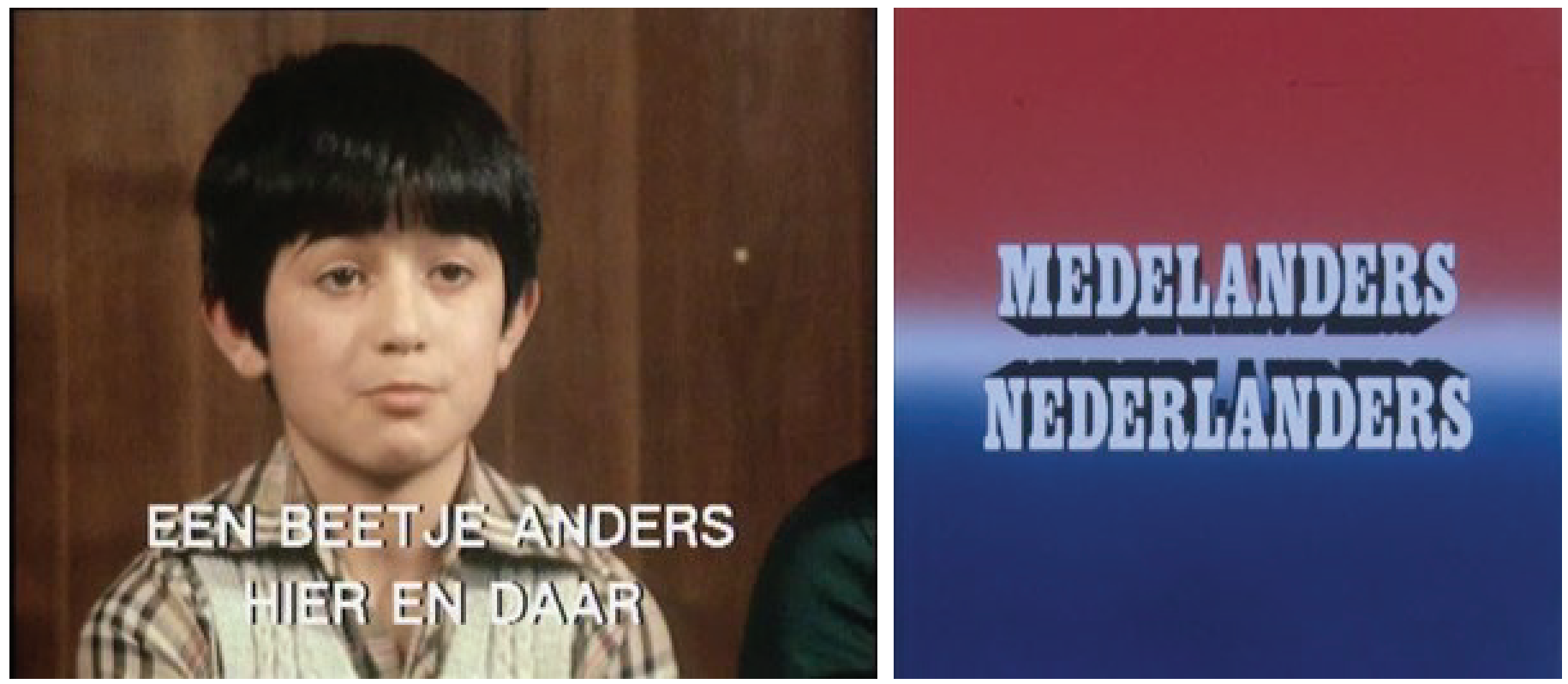

Figure 5. Stills from the titles of the programmes Een Beetje Anders Hier en Daar (KRO, 25-10-1982) and Medelanders Nederlanders (KRO, 05-09-1981).

In this new discursive formation, the archival descriptions of programmes about Turkish and Moroccan immigrants replaced the keyword "foreign workers" with "ethnic minorities" ("etnische minderheden"). An increasing amount of these programmes were labelled with "Muslims" and "Islam."49 In these years, the Moroccan and Turkish immigrants were mainly spoken of in terms of ethnicity and culture, while their religious identity became more visible on television. The predominant themes that ran through the television coverage of "ethnic minorities" were their unemployment, their deprived socio-economic conditions, remigration, the arrival of the second generation, the emancipation of women, education of the second generation, the emergence of "black" schools, and racism and discrimination by the Dutch..$^{50}$ In line with government policy, television advocated tolerance in various special programmes about ethnic minorities, such as Een Beetje Anders Hier en Daar (A Little Different Here and There) and Medelanders Nederlanders (Immigrants Fellow Dutch) (see figure 5). Here - and this is rather symptomatic for the culturalisation of the discourse in these years - television advocated tolerance by emphasising cultural and ethnic difference. Increasingly, television began to use the ethnicity, culture and religion of Turkish and Moroccan immigrants as markers of difference and, in Malik's phrasing, as homologues of race..$^{51}$ 

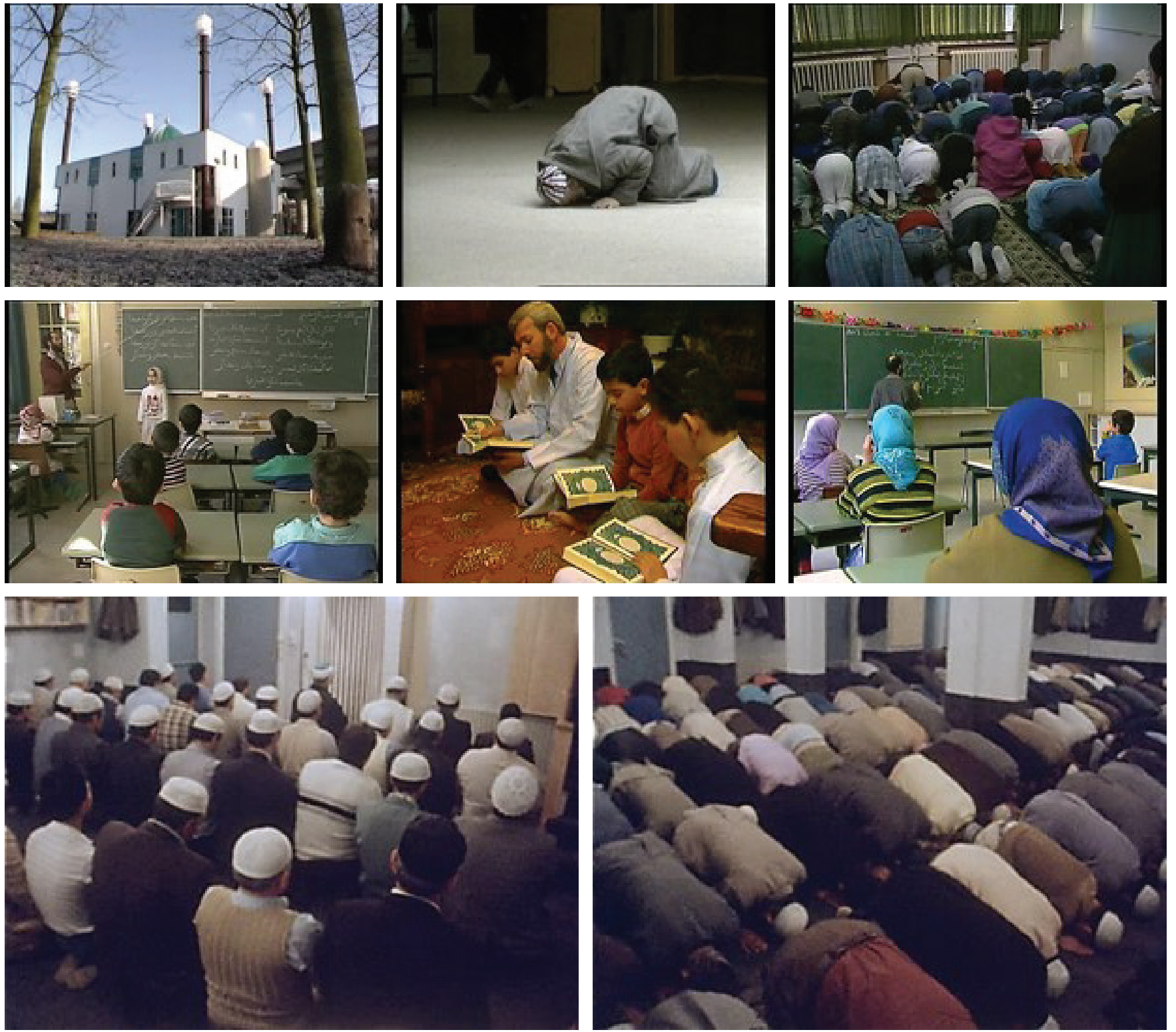

Figure 6. A selection of stills from Televizier (AVRO, 07-03-1986) (a), Tijdsein (EO, 23-11-1988) (b), Kenmerk (IKON, 13-02-1989) (c, d, e), Achter het Nieuws, (KRO, 19-03-1989) (f), and Brandpunt (KRO, 04-07-1983) (g, h)

In the television coverage that addressed the Islamic identity of the Turkish and Moroccan immigrants (and that was also labelled with "Islam"), the variety of themes associated with Islam began to broaden. Television now reported on the efforts of Muslim immigrants to institutionalise their religious rituals, on the opening of mosques and on the nature of (contested) rituals such as halal slaughter and circumcision. ${ }^{52}$ Women and children gradually entered the televisual narratives and television began to report on the foundation of Islamic schools and on the (alleged oppressed) position of Islamic women..$^{53}$ And finally, towards the end of the decade (in particular after the Rushdie affair in 1989), the issue of Islamic fundamentalism entered television's news agenda. ${ }^{54}$ While the typical Muslim on television was still male, praying, celebrating meals with his family, opening mosques and Islamic schools, he began to be occasionally suspected of having fundamentalist ideas and of being implicated in religious practices that were seen in conflict with the values of the Dutch nation. In addition to the familiar images of communal prayers, exteriors and interiors of mosques, close-ups of Arabic writing, and the celebration of Islamic festivities, new images entered the repertoire, such as children attending Quran school and young veiled girls in the newly opened Islamic schools (see figure 6). 
Since television now began to use the familiar imagery of the Muslim's prayer and place of worship in stories that did not deal with actual practices of Islam, or in stories that framed these practices as problematic, the religious imagery began to operate as a marker of otherness and began to gradually gain negative and stereotypical connotations. Television's gaze now started to not only display fascination for the Muslim other but also fear.
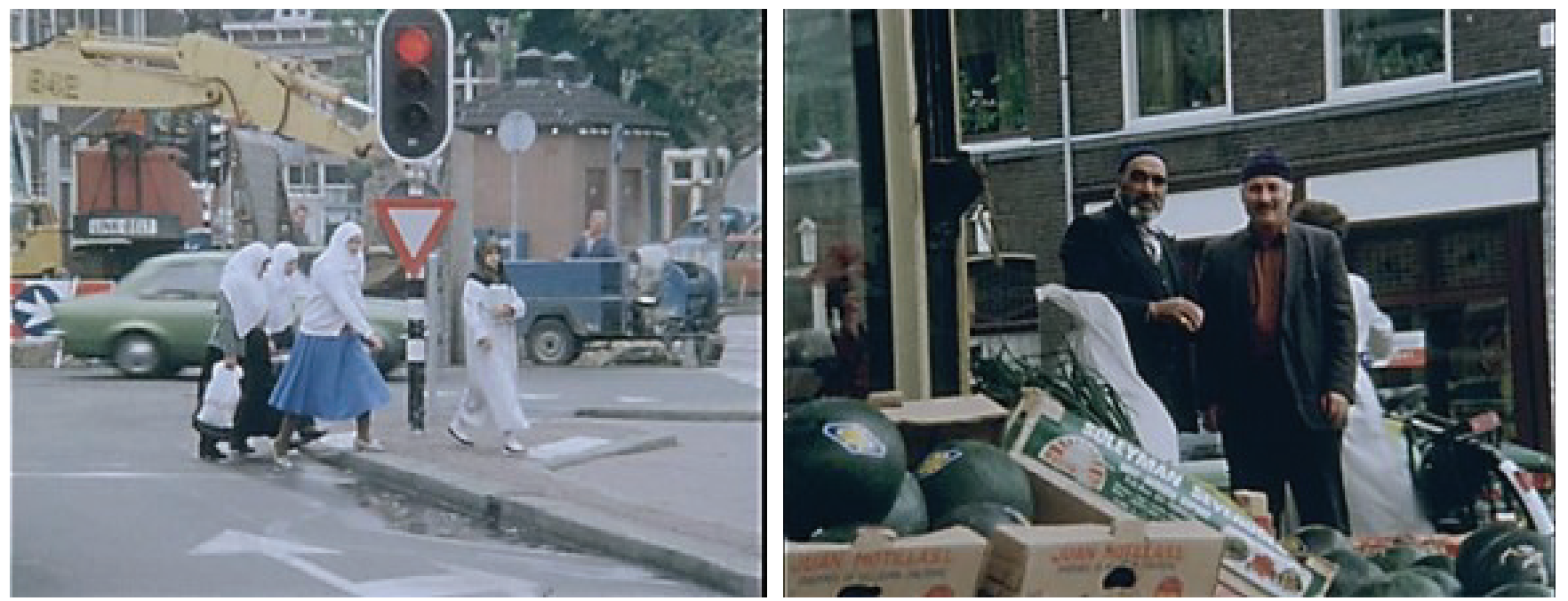

Figure 7. Stills from Brandpunt (KRO, 04-07-1983)

Additionally, television started to visualise its stories with all sorts of images of (Muslim) migrants and veiled women in public spaces, including markets, streets and Islamic butcheries (see figure 7). Here, television's gaze was completely structured around, in Balibar's words, "the stigmata of otherness" of these migrants: around their different skin colour, physical appearance and dress. ${ }^{55}$ Dutch photographer Cigdem Yuksel has coined this kind of imagery "safari" images; a term that I find apt to describe television's unifying racialising gaze that is at play here, as it tracks non-white ethnicity and otherness 'in the wild'. ${ }^{56}$ The emergence of these safari tropes is symptomatic - I argue - for television's discovery that these (Muslim) migrants were here to stay and were already part of the fabric of Dutch society. Television began to use these safari tropes both in more general stories about "ethnic minorities," and in stories that explicitly revolved around Islam and even Islamic fundamentalism (see figure 8). Thereby, television constantly stressed the otherness of Turkish and Moroccan migrants and, in the latter case, associated them with Islamic fundamentalism on the basis of their physical appearances.
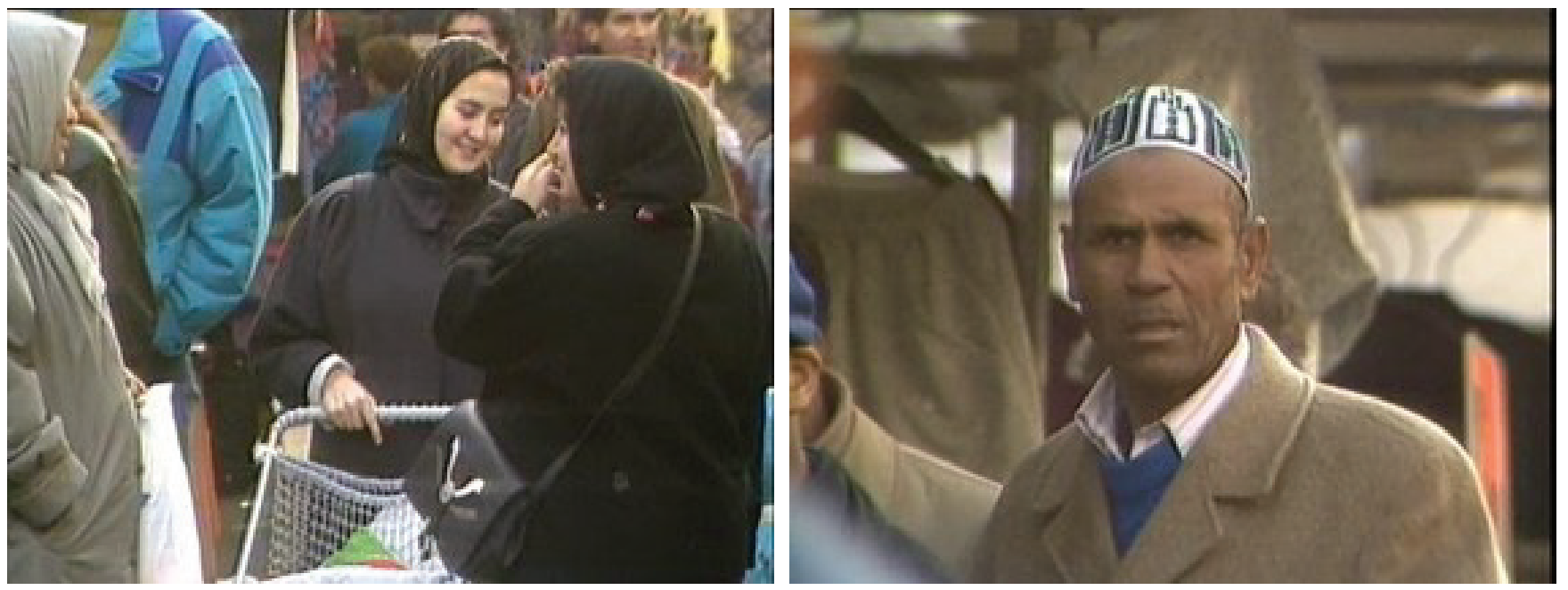

Figure 8. A selection of safari tropes from Tijdsein (EO, 23-11-1988), that revolved around the dangers of Islamic fundamentalism. 
Again, the archive of Sound and Vision has insistently highlighted the core generic images of television's visual repertoire of Muslim immigrants as stock shots for reuse. The descriptions kept earmarking shots of exteriors and interiors of mosques (e.g. "int. and ex. mosque in the Netherlands" ${ }^{57}$ ) and communal prayers (e.g. "prayers of Muslims,"58 "Muhammadan prayer"59). Over and over again, the archive has attributed importance to images of the Muslim's prayer and place of worship and has further enhanced the iterativity (the timelessness, memorability and quotability) of this kind of generic imagery. The archival descriptions also started to reiterate the safari images of (Muslim) immigrants in public space. The archival descriptions mentioned for example: "diverse shots of Muslims on the market" 60 and "market in the Netherlands with a lot of ethnic minorities" 61 (see figure 9). These descriptions, that were obviously purely based on the bodily appearances and dress of the people depicted on television, further naturalised and reified their otherness.

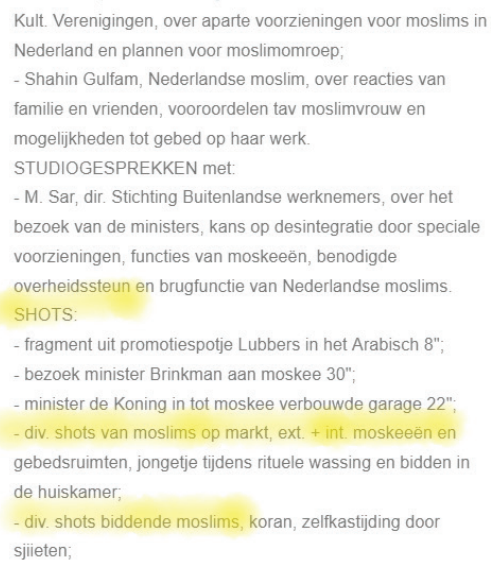

Figure 9. Examples of description of stock shots in a. Televizier (AVRO, 07-03-1986) (besides "div. shots of praying Muslims" and "ext. and int. mosque," the description mentions "div. shots of Muslims on the market) and b. De Islam (STV, 11-11-1987)

("market in the Netherlands with a lot of ethnic minorities").

\section{The Nineties: The Discursive Formation of Allochtonen and the Emergence of Hostility towards Muslims}

In the 1990s, the attitude of the Dutch government towards the preservation of the cultural identities of immigrants came under pressure as the result of the publication in 1989 of a report by the Advisory Council on Government Policy ("Allochtonenbeleid"), that warned that the integration of minorities was bound to fail. The publication of this report ushered the era of what Baukje Prins described a "new realism". ${ }^{62}$ The government implemented a new policy that demanded more participation from minorities, that addressed them as individuals instead of groups, and that focused on their integration in Dutch society. The Rushdie affair (1989) had aroused anti-Islam sentiments and politicians such as Frits Bolkestein and Pim Fortuyn took a lead in the promotion of a hostile attitude towards Muslims. Over the course of the nineties, the public debate on immigration, the multicultural society and Islam began to harden.

In this new discursive formation, television becomes preoccupied with the issue of the multicultural society and the integration of "allochtonen." Both in the archive of Sound and Vision and on television, the labels "ethnic minorities," "allochtonen" and "Muslims" started to become discursively entangled. ${ }^{63}$ In these years, television privileged narratives of (Moroccan) criminality, segregation in impoverished old city quarters, the continuing socio-economic deprivation of minorities, unemployment, discrimination and racism, the position of migrant women and other integration issues. ${ }^{64}$ Television reported on the increasing fear of Islamic fundamentalism, on the emerging hostility towards Islam, on the 
rise of Islamic schools, and on various issues relating to the (alleged failed) integration of Muslims. This decade witnessed television's mounting obsession with the figure of the veiled Muslim woman, framed as either repressed or emancipated in the televisual narratives. ${ }^{65}$
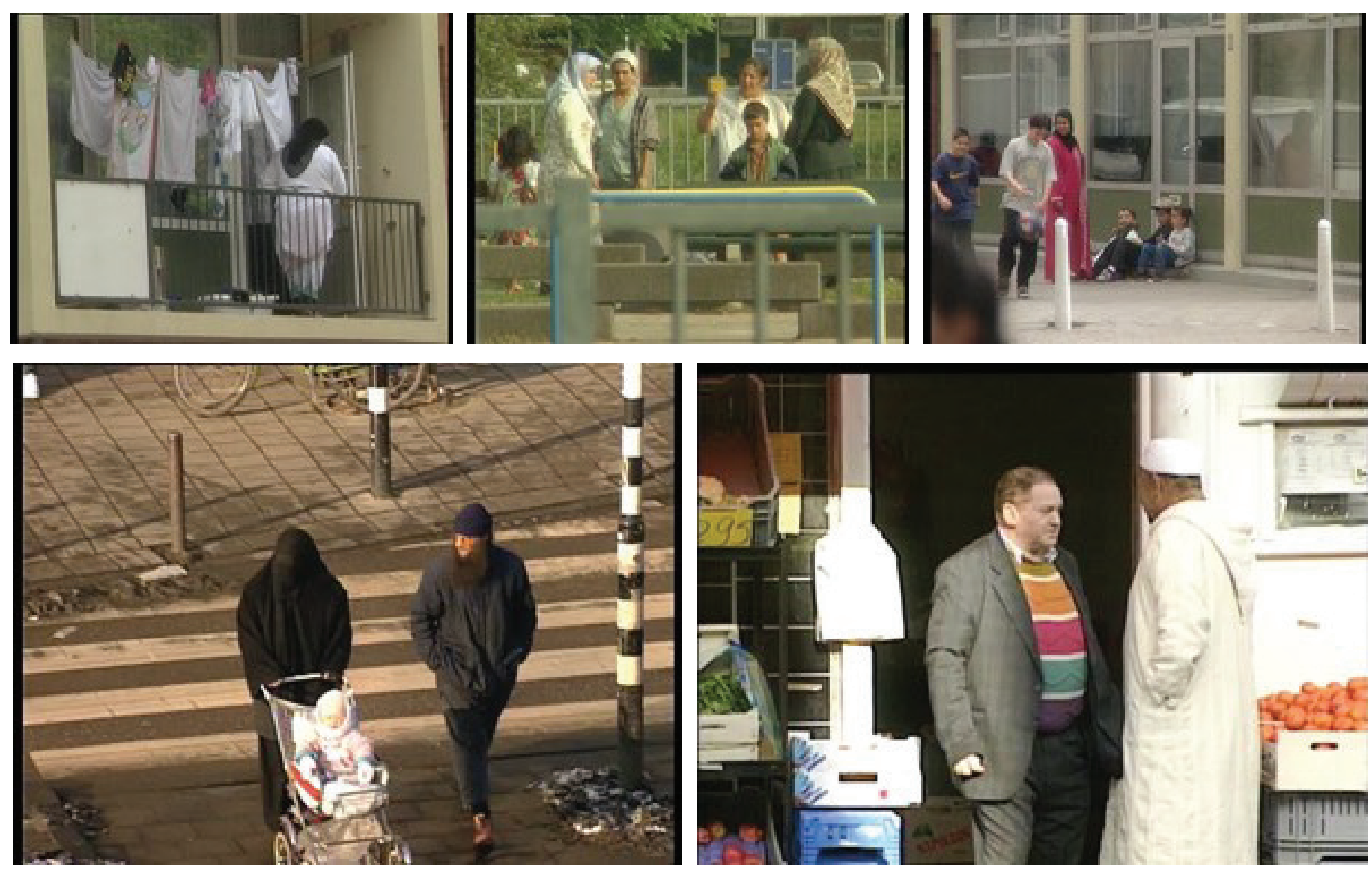

Figure 10. Examples of safari tropes from: Twee Vandaag (25-05-1998) (a-c), Impact (VARA, 19-03-1991) (e), and Achter het Nieuws (VARA, 28-01-1992).

Television's preoccupation with the allochtoon, the Muslim and the issue of integration produced an increasingly racialised visual repertoire. Television's inclination to use safari tropes - Muslim looking men (often bearded and wearing traditional dress) and veiled women on markets and streets - intensified immensely (see figure 10). The veiled woman in public space became a recurrent visual motif in all sorts of narratives about the problems of multicultural society and the alleged failed integration of Muslims. ${ }^{66}$ Television's obsessive repetition of images of veiled women and Muslim looking men on the street now began to take the form of, in Bhabha's phrasing, a "fetishistic mode of representation" and reflected an increasing fear for non-white ethnicity and Islam, and a need to delineate 'us' (the white and Christian Dutch nation) from 'them.' ${ }^{67}$ Furthermore, generic images of mosques and prayers as markers of otherness were now repeatedly used to visualise stories about the lack of integration of Muslims and the dangers of Islamic fundamentalism, thus accruing more stereotypical and racialised connotations (see figure 11). ${ }^{68}$ Thereby, television homogenised Muslims as badly integrated and potentially dangerous on the basis of their religious practices and further contributed to the process of their racialisation. 

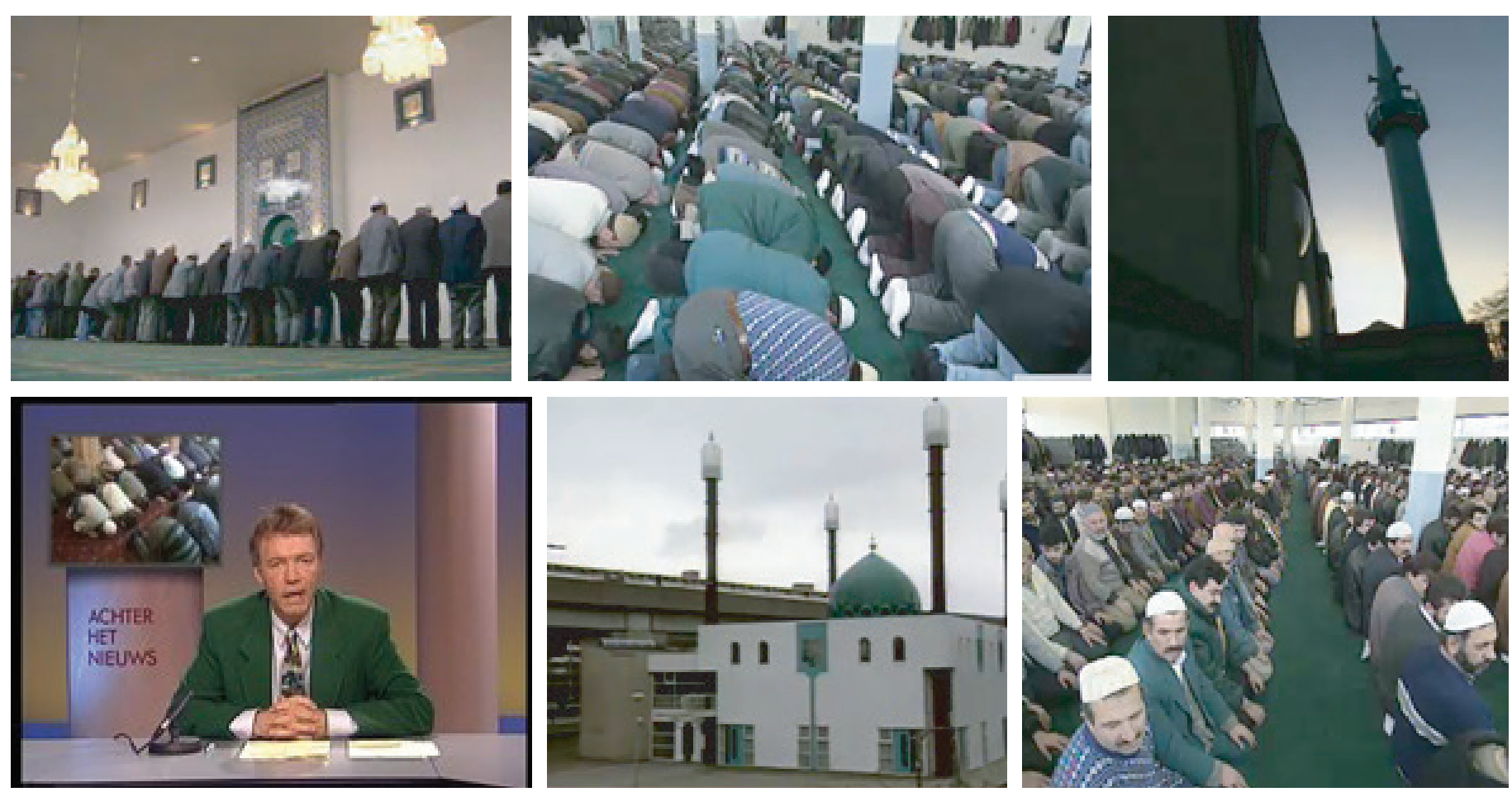

Figure 11. Stills from Tijdsein (23-10-1996) about the failed integration of Muslims (a, e), Hier en Nu (13-03-1995) (b, c, f) and Achter het Nieuws (28-01-1992) about the rise of Islamic fundamentalism.

The archive of Sound and Vision continued to play a performative role in television's dissemination of these racialised tropes of Muslim otherness. The detailed shot descriptions kept highlighting exteriors and interiors of mosques and communal prayers and thereby kept adding to the iterativity of these visual stereotypes of Muslim otherness. Besides, stock shots of Muslim men, women and children in public space began to dominate the archival descriptions and began to take various forms, such as: "diverse shots of Muslims," "diverse street shots with allochtonen and women with headscarves," 69 "diverse shots of Muslims in mosques, shops, and tearooms," 70 "street shots with Muslims," "Muslims on the street,"71 "shopping Muslim women,"72 "veiled women at the market," "Muslims in an Islamic butchery," and "women with headscarves on the street" (see figure 12). Here, 'Muslimness' was read from these individuals on the basis of physical appearances and operated as a signifier of non-white and non-Dutch otherness. Obviously, these archival descriptions not only reflected television's obsession with and fear of Muslims, but also further contributed to the process of racialisation of Muslims and to the consolidation of a rigid iconography that consisted of a small amount of stock stereotypes. 


\section{NETWERK}

0:09:33

PIM FORTUYN: BOEK "TEGEN DE ISLAMISERING VAN ONZE CULTUUR"

Met zijn boek "Tegen de islamisering van onze cultuur" heeft Pim Fortuyn voor beroering gezorgd. Hij schrijft daarin dat de oude Nederlandse wijken broedplaatsen voor fundamentalisten zijn; dat Nederland vol is; pleit ervoor de toelating van vluchtelingen te stoppen en de immigranten zo snel mogelijk te spreiden en integreren. Fortuyn leest een aantal fragmenten voor en discussieert met een Turkse studente. INTERVIEWS hierover met:

- dr. Pim Fortuyn, auteur;

- Annemarie Grewel, Eerste-Kamerlid PvdA, fel tegenstander van de uitspraken van Fortuyn (quote "hij heeft het boek gepoept");

- N. Öztürk, studente

SHOTS:

- div. shots van Pim Fortuyn oa op straat, in moskee, achter bureau;

cu van boek "Tegen de islamisering van onze cultuur":

div. straatshots met allochtonen en vrouwen met hoofddoeken;

cu Turkse krant, Turken in koffiehuis;

- biddende en lezende man in moskee.

\author{
hierop, de noodzaak van werk en scholing inkv het \\ integratieproces, het beleven van de religie door moslims. \\ INTERVIEWS hierover met oa: \\ - Prof. dr. mr. Jan Brugman, arabist, \\ - Paula d'Hondt-van Opdenbosch, minister van Staat, België \\ - prof. dr. Mohammed Arkoun, islamdeskundige; \\ - Daniel Cohn-Bendit, wethouder vreemdelingen zaken in \\ Frankfurt, over het falend beleid van de Duitse overheid, wat \\ betreft voorlichting aan de Duitsers over migranten; \\ - Ali Haydar, aleviet (islamitische geloof), vertelt over de \\ gelijkwaardige positie van de vrouw tov de man in zijn \\ geloof; \\ - Marokkaan Mousid Akamrane, kampioen kickboksen, over de \\ familieband en de vriendschap in het algemeen; \\ SHOTS: \\ 22:41:30 winkelende moslim vrouwen; \\ 22: $42: 49$ div. shots van een moskee met biddende mensen; \\ 22:46:03 scheepvaart op de Bosporus met Aya Sofia; \\ 22:47:14 Duitse politiebus in actie in Frankfurt; \\ 22:59:29 henna-avond in Dordrecht; \\ 23:03:27 anti-racistische leuzen op Duitse flat: \\ 23:03:43 fragment uit racistische film "Stau, jetzt geht \\ los"; \\ 23:09:26 wedstrijd kickboksen \\ $22 \cdot 11 \cdot 15$ allanhtamn inn maran tia
}

$\begin{array}{ll}\text { slection type } & \text { item } \\ \text { tle } & \text { LTI107850_POS6250387 } \\ \text { sngth } & \text { JOURNAAL } \\ & 0: 01: 39\end{array}$

ong Summary Verslag Pauline Broekema (stand-up), discussieavond in moskee in Den Haag om te praten over toenemende rassendiscriminatie en vreemdelingenhaat:

SHOTS straatshots met etnische minderheden (oa vrouwen met hoofddoeken) $8 "+14 "$ " ext. islamitische slagerij $3^{\prime \prime}$

INTERVIEW met eigenaar van islamitische slagerij over racisme in Den Haag

」bject terms

Name

etnische minderheden

hanfdragkan

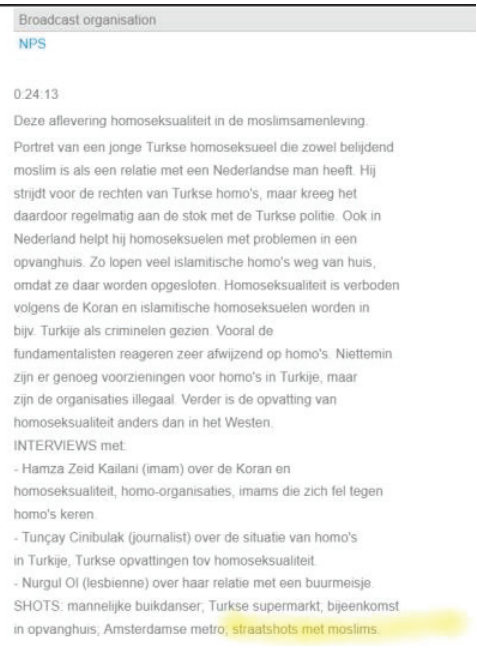

\section{JEUGDJOURNAAL}

$00: 13: 38: 00-00: 16: 41: 24$ ITEMIPROGRAM

MIDDELPUNT. Portretje van moslim-jongetje Kedir in Nederland, met goede SHOTS van biddende moslims in moskee, meisjes met hoofddoekjes in klas, moslim-gezin...

Figure 12. Examples of description of stock shots in a. Netwerk (AVRO, 13-02-1997) (besides "praying and reading man in mosque", the description mentions "div. street shots with allochtonen and women with headscarves"), b. Nieuwe Buren (AVRO, 10-03-1994) (besides "diverse shots of a mosque with praying people," the description mentions: "shopping Muslim women"), c. Journaal (NOS, 12-02-1992) ("street shots with ethnic minorities and women with headscarves"), d. Tijdcodes (16-01-1992) ("street shots with Muslims") and e. Jeugdjournaal (NOS, 13-03-1992) ("with nice shots of praying Muslims in a mosque and girls with headscarves in class"). 


\section{2000-2010: The Discursive Formation of Dangerous Muslims and Failed Integration}

During the first few years of the new millennium, the publication of Paul Scheffer's "The Multicultural Drama" (2000) and the traumatic events of 9/11 (2001) and the assassination of filmmaker Theo van Gogh (2004) by a radicalised Dutch Muslim seriously disturbed the country and resulted in an extreme polarisation of the debates about integration, multiculturalism and Islam. ${ }^{73}$ Throughout the decade, several incidents and events, such as the rise of populist politician Geert Wilders and the controversy surrounding his anti-Islam film Fitna (2008), caused commotion in Dutch society. The debates about integration and multiculturalism now began to completely centre on Islam and integration became the buzzword of this era. And the latent fear of Islam that had surfaced from the end of the eighties was now fully projected onto Dutch Muslims.
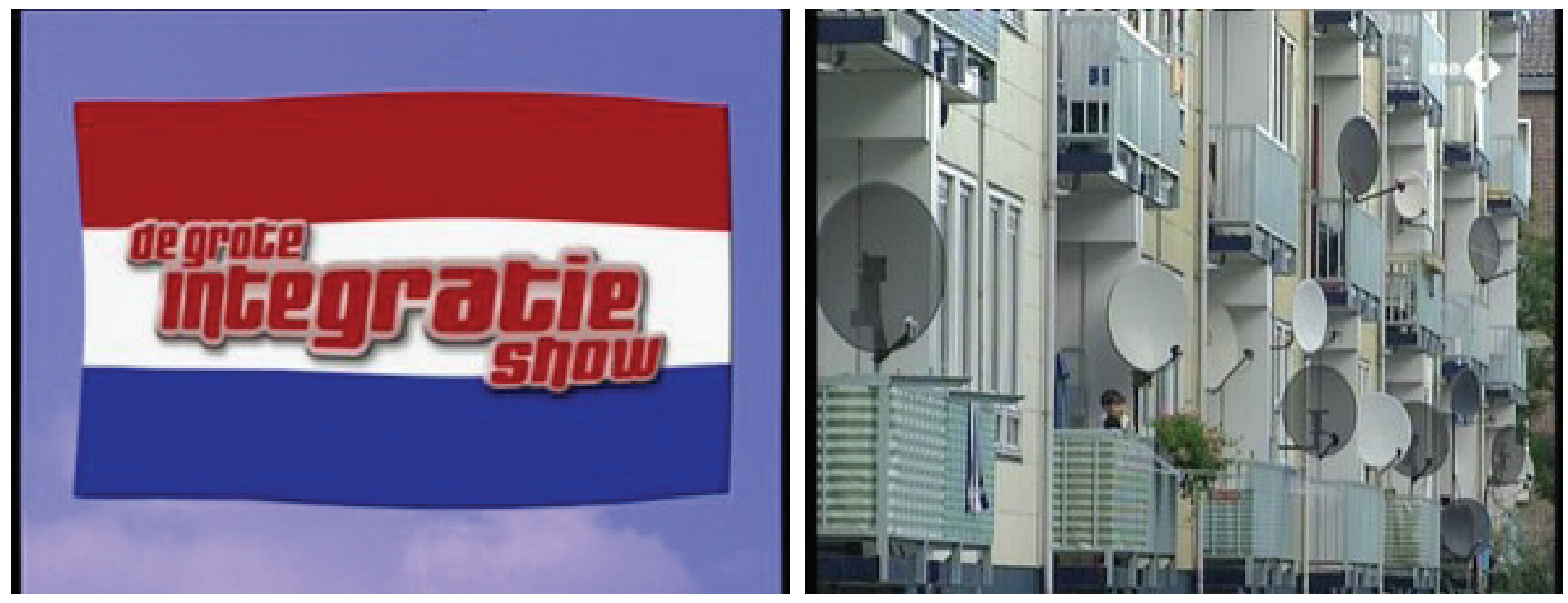

Figure 13. Stills from De Grote Integratieshow (The Great Integration Show) (BNN, 2002) and from Netwerk (KRO, 23-09-1002) about failed integration.

Not surprisingly, in this discursive formation television became obsessed with stories about the alleged failure of integration of (Muslim) immigrants and the amount of programmes that were tagged with the keywords "Muslims"/ "Islam" increased dramatically compared to the nineties. Both on television and in the archive, the topics of "ethnic minorities," "allochtonen" and "Muslims" became very much entwined. ${ }^{74}$ Television continued to report on issues related to the (alleged) lack of integration of allochtonen, such as segregation in old city quarters, segregation in the realms of education and 'black' schools, and (Moroccan) criminality. ${ }^{75}$ Besides, television became totally fixated on the 'Islam debate' and on the issues of the radicalisation of young Muslims, 'home-grown' terrorism, hate-preaching imams, contested mosques, fundamentalism in Islamic schools, repressed veiled women, women in 'burqa' and other issues associated with fundamentalism and terrorism. ${ }^{76}$ In this discursive formation, the radicalised and fundamentalist Muslim and the fully covered Muslim women became the exemplary figures of the allochtoon whose integration had ultimately failed. 

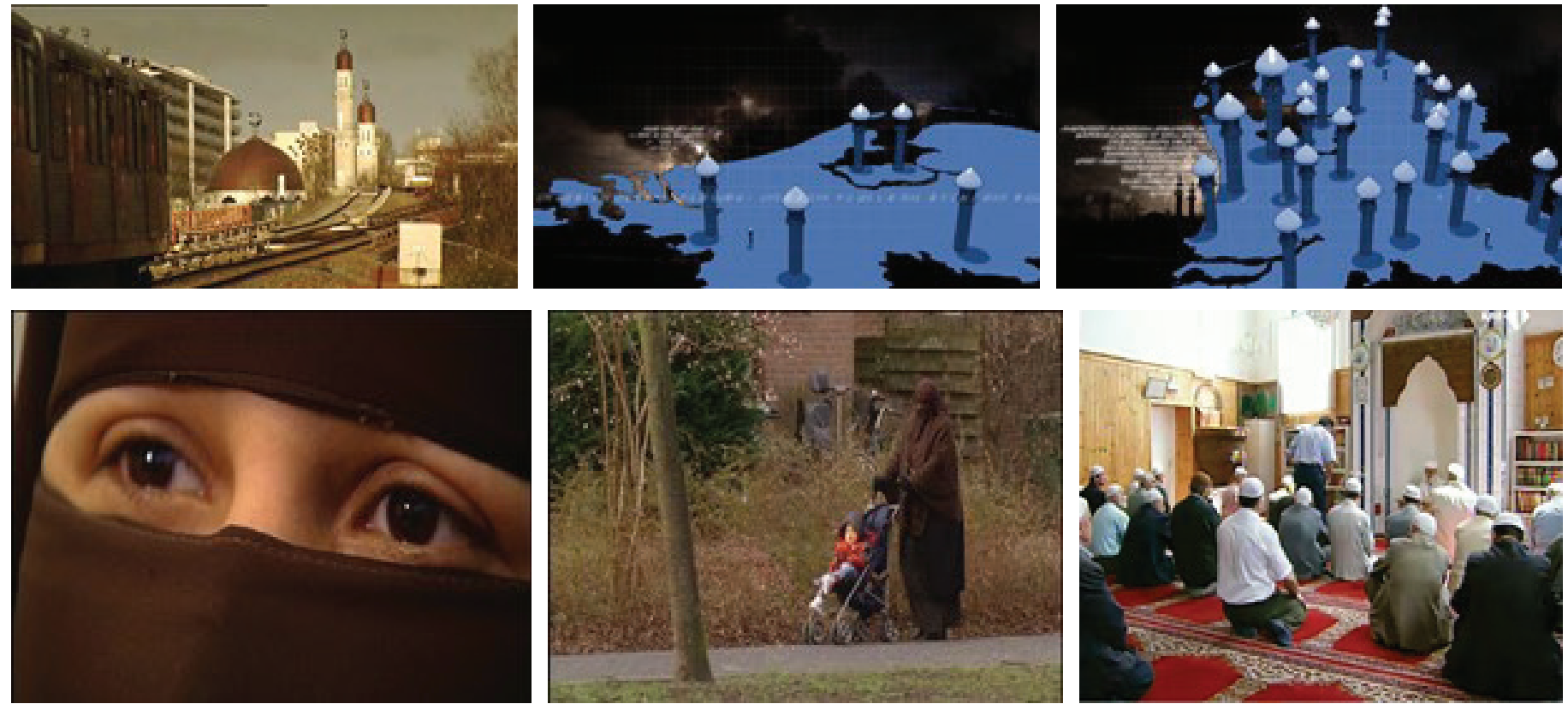

Figure 14. Stills from Reporter (KRO, 04-02-2007) about Islamic fundamentalism (a, b, c), EenVandaag (TROS, 08-02-2008) about failed integration $(d, e)$ and Netwerk (EO, 06-05-2002) about Islamic extremism (f).

In these years, the racialisation of television's visual repertoire of Muslims further intensified. Safari images of veiled women (sometimes fully covered) and Muslim looking men on streets and markets dominated the repertoire of television's stories about the failure of integration of allochtonen and the dangers of Islamic extremism and fundamentalism. Besides, television often visualised stories about Islamic fundamentalism and terrorism with the familiar images of communal prayers and mosques, that now became heavily burdened with even more negative connotations (see figure 14). By constantly associating the Muslim's place of worship, the Muslim's dress and the Muslim's prayer with failed integration, fundamentalism and terrorism, television racialised these religious markers of identity and amalgamated Muslims into a homogenous group with innate characteristics, such as violence, extremism, misogyny and incompatibility with Dutch values. Television's compulsive repetition of these visible symbols of Islam clearly displayed an increasing fear for the 'Islamification' of the Dutch nation (see figures 14 and 15).
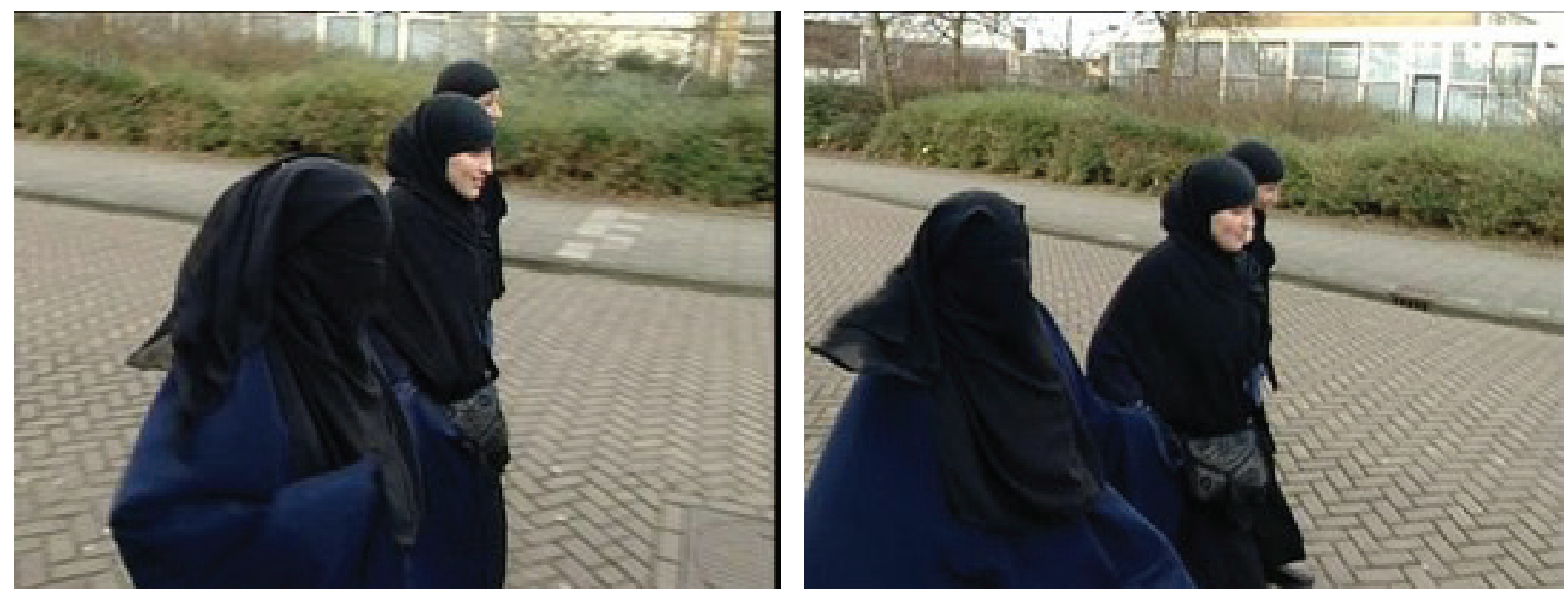

Figure 15. Stills from TweeVandaag (EO, 03-02-2002) about women wearing "burqa" 
Yet again, the archival descriptions of the broadcast material kept persistently reiterating all these dominant stock stereotypes: exteriors and interiors of mosques, (communal) prayers, veiled women on the market, and allochtonen and Muslims on the street (see figure 16). Descriptions such as "Muslims on the street," "shopping veiled Muslim women," "orthodoxly dressed Muslims," "Muslim women with burqa" and "young Dutch Muslim woman with niqab at the table with blond parents" evidently exhibited fear for contamination of the Dutch identity by Islam and revealed the continuing racialisation of Muslims (see figure 16). And again, these descriptions were designed to duplicate these visual stereotypes and thereby further added to their iterativity, even as additional connotations were added, as we have seen above.

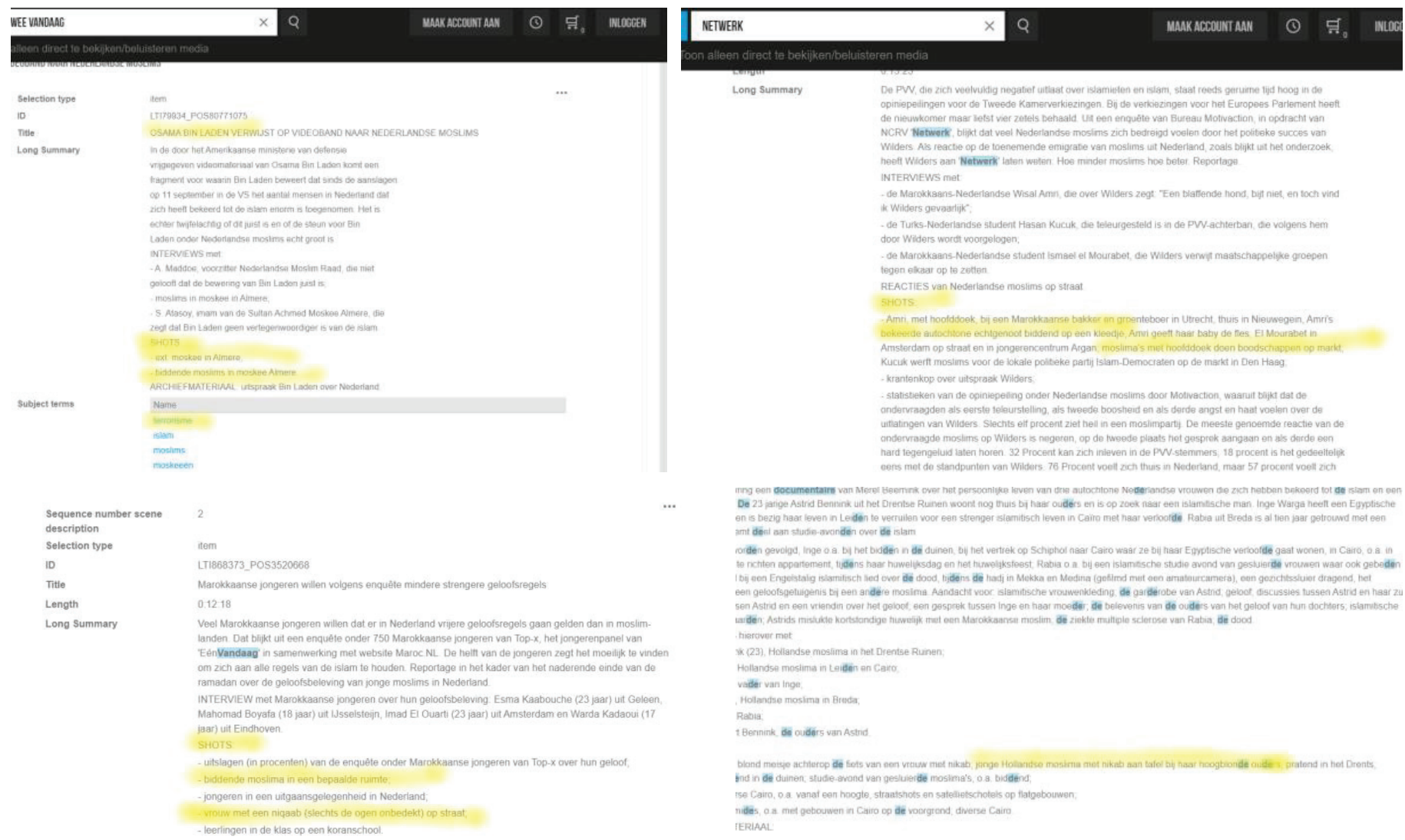

Figure 16. Examples of description of stock shots in a. Netwerk (09-12-2002) (the description of this item about Muslim terrorism mentions "ext. mosque in Almere and "praying Muslims in a mosque in Almere"), b. Netwerk (29-06-2009) ("veiled Muslim women shopping on the market"), c. Twee Vandaag (29-09-2008) ("praying Muslims" and "woman with niqab (only eyes uncovered) in the street") and d. De Donderdag Documentaire (IKON, 01-12-2005) ("young Dutch Muslim woman with niqab at the table with blond parents").

\section{Conclusion}

By tracing the history of Dutch television's representation of Muslim immigrants through the lens of the Sound and Vision archive, this article has demonstrated that during their symbolic transformation from "guest workers" to "ethnic minorities" to "allochtonen" and "Muslims," television's rigid visual repertoire became increasingly racially inscribed. The generic images of mosques and communal prayers now carry connotations far beyond their initial significance and have become stock stereotypes. Where in the initial decades of Islamic immigration, these images illustrated stories about the actual rituals and practices of Islam, from the eighties onwards they have compulsively been employed in a wide 
range of stories, such as the failure of integration and the dangers of Islamic fundamentalism and terrorism. Also, images of veiled women and Muslims in public spaces - the safari tropes that emerged in the eighties - have been similarly transformed. By obsessively repeating the same images over and again in stories that did not necessarily deal with the rituals and appearances of the Islamic religion, television has suggested causal relations between the religion of Islam and all sorts of societal problems and has amalgamated Muslims into a homogenous group. Images of the Muslim's place of worship, the Muslim's religious prayer, and the Muslim's bodily appearance have emerged as racialised through this process of reiteration and have become heavily burdened with stereotypical connotations. These images have been used to mark the strangeness, otherness and sometimes even the threat of Muslims, and they evidently displayed a fear of contamination of the white Dutch nation by Muslim immigrants.

The resilience of these stereotypical images resides - I argue - not necessarily in their semantic content, but in their high degree of iterativity: their timelessness, memorability and quotability. Finally, the archive of Sound and Vision has played a performative role in the development of this process of stereotyping into a vicious circle by persistently translating television's stock stereotypes of Muslim immigrants into instantly quotable visual units. Its practice of describing stock shots such as praying Muslims and veiled women on the market was aimed at facilitating further duplication of these already stereotyped and racialised images. And since these descriptions were purely based on the physical appearances of Muslim immigrants, the archive has constantly naturalised, reiterated and reified the process of racialisation. For future research, it would be interesting to further ground this argument empirically, by using image recognition tools that are currently being developed to map the actual reuse of the footage that has been highlighted by the archival descriptions.

\section{Notes}

1. Philomena Essed and Isabel Hoving, eds., Dutch Racism (New York: Brill, 2014), 9.

2. The word 'allochtoon' had been coined in 1971 by the sociologist Hilda Verweij-Jonker and refers to immigrants and their descendants (as opposed to autochtoon: ethnic Dutch). Although the term was proposed as a neutral term, it has been criticised for being stigmatizing. Since 2016, the Dutch government has stopped using the term.

3. See for instance: Edward Said, Covering Islam. How the Media and the Experts Determine How We See the Rest of the World (London: Vintage Books, 1981); Kai Hafez, ed., Islam and the West in the Mass Media. Fragmented Images in a Globalizing World (Cresskill: Hampton Press, 2000); Elizabeth Poole, Reporting Islam. Media Representations of British Muslims (London and New York: Tauris, 2002); Elizabeth Poole and John Richardson, eds., Muslims and the News Media (London: Tauris, 2006); Karim H. Karim, Islamic Peril. Media and Global Violence (Montreal and New York: Black Rose Books, 2003); Brigitte Nacos and Oscar Torres-Reyna, Fueling Our Fears. Stereotyping, Media Coverage, and Public Opinion of Muslim Americans (New York: Rowman and Littlefield Publishers, 2007); Peter Morey and Amina Yaqin, Framing Muslims. Stereotyping and Representation after 9/11 (Cambridge and London: Harvard University Press, 2011); Evelyn Alsultany, Arabs and Muslims in the Media: Race and Representation After 9/11 (New York: NYU Press, 2010); Julian Petley and Robin Richardson, eds., Pointing the Finger. Islam and Muslims in the British Media (Oxford: Oneworld, 2011); Stefan Mertens and Hedwig de Smoek, Representations of Islam in the News: A Cross-Cultural Analysis (Lanham: Lexington Books, 2016).

4. Hardly any work has been done on Dutch media coverage of minorities in general and Muslims in particular. See for publications on Dutch media representation of minorities: Teun van Dijk, Minderheden in de Media. Een Analyse van de Berichtgeving over Etnische Minderheden in de Pers [Minorities in the Media. An analysis of Press Coverage of Ethnic Minorities] (Amsterdam: SUA, 1983); Andra Leurdijk, Televisiejournalistiek over de Multiculturele Samenleving [Television Journalism about the Multicultural Society] (Amsterdam: Het Spinhuis, 1999); Huub Evers and Carmelita Serkei, eds., Naar een Interculturele Journalistiek. Beschouwingen over Media en Multiculturele Samenleving [Towards Intercultural Journalism. Reflections on Media and Multicultural Society] (Amsterdam: Aksant, 2007); Garjan Sterk and Bart Top, eds., Media and Allochtonen. Journalistiek in de Multiculturele Samenleving [Media and Minorities. Journalism in the Multicultural Society] (Den Haag: SDU Uitgevers, 2000). There are only a few publications on the representation of Muslims in the Dutch media: Ron Haleber, ed., Rushdie Effecten. Afwijzing van Moslim-Identiteit in Nederland? [Rushdie Effects. The Rejection of Muslim Identity in the Netherlands] (Amsterdam: SUA, 1989); Wasif Shadid, "Berichtgeving over Moslims en de Islam in de Westerse Media" [Coverage of Muslims and Islam in Western Media], Tijdschrift voor Communicatiewetenschap 33, no. 4 (2005): 330-340; Leen D'Haenens and Susan Brink, "Islam in the Dutch Press, with Special Attention to the Algemeen Dagblad," 
Media, Culture \& Society 29, no. 1 (Winter, 2007): 135-161; Wasif Shadid, "Moslims in de Media. De Mythe van de Registrerende Journalistiek" [Muslims in the Media. The Myth of Recording Journalism] in Mist in de Polder. Zicht op Ontwikkelingen omtrent de Islam in Nederland [Fog in the Polder.A View on Developments regarding Islam in the Netherlands], eds. Sipco Vellenga, Sadik Harchaoui, Halim El Madkouri, Baukje Sijses (Amsterdam: AUP, 2009).

5. See for discussions about the concept of racialisation for instance: Rohit Barot and John Bird, "Racialization. The Genealogy and Critique of a Concept," Ethnic and Racial Studies 24, no. 4 (2001): 601-618; Herbert J. Gans, "Racialization and Racialization Research," Ethnic and Racial Studies 40, no. 3 (2017): 341-352; Adam Hochman, "Racialization. A Defense of a Concept," Ethnic and Racial Studies 42, no. 8 (2019): 1245-1262; Bianca Gonzalez-Sobrino and Devon R. Goss, "Exploring the Mechanisms of Racialization beyond the Black-White Binary," Ethnic and Racial Studies 42, no. 4 (2019): 505-510.

6. See for instance: Kenan Malik, The Meaning of Race. Race, History and Culture in Western Society (Houndmills, Basingstoke, Hampshire and London: Macmillan Press, 1996); Etienne Balibar, "Is there a 'Neo-Racism'?," in Race, Nation, Class.

Ambiguous Identities, eds. Etienne Balibar and Immanuel Wallerstein (London and New York: Verso, 1991); Teun van Dijk, Racism and the Press (London: Routledge, 1991); Teun van Dijk, "New(s) Racism. A Discourse Analytical Approach," in Ethnic Minorities and the Media, ed. Simon Cottle (Buckingham and Philadelphia: Open University Press, 2000); Gloria Wekker, White Innocence. Paradoxes of Colonialism and Race (North Carolina: Duke University Press, 2016).

7. Michael Omi and Howard Winant, Racial Formations in the United States. From the 1960s to the 1990s (3 ${ }^{\text {rd }}$ ed, New York: Routledge, 2014), 111.

8. Malik, The Meaning of Race, 150.

9. Balibar, "Is there a 'Neo-Racism'?,” 17-21.

10. Steve Garner and Saher Selod, "The Racialization of Muslims. Empirical Studies of Islamophobia," Critical Sociology 41, no. 1 (2015): 12.

11. Homi K. Bhabha, "The Other Question. Difference, Discrimination and the Discourse of Colonialism," in Out There. Marginalization and Contemporary Cultures, eds. Russel Ferguson, Martha Gever and Felix Gonzalez-Torres (Cambridge and London: MIT Press, 1990), 81.

12. Rey Chow, The Protestant Ethnic and the Spirit of Capitalism (New York: Columbia University Press, 2002); Mireille Rosello, Declining the Stereotype. Ethnicity and Representation in French Cultures (Hanover and London: University Press of New England, 1998).

13. Chow, The Protestant Ethnic, 54.

14. Rosello, Declining the Stereotype, 37

15. Ibid., 25.

16. This constructivist paradigm of archives has been instigated by and described in the works of e.g.: Michel Foucault, The Archaeology of Knowledge, trans. A. M. Sheridan Smith (London and New York: Routledge, 2006); Jacques Derrida, Archive Fever. A Freudian Impression, trans. Eric Prenowitz (Chicago and London: University of Chicago Press, 1995); Ann Laura Stoler, "Colonial Archives and the Arts of Governance: On the Content in the Form," in Refiguring the Archive, ed. Carolyn Hamilton et al (Dordrecht, Boston, London: Kluwer Academic Publishers, 2002), 83-103; Eric Ketelaar, "Tacit Narratives: The Meaning of Archives," Archival Science 1, no. 2 (2001): 131-141; Tom Nesmith, "Seeing Archives: Postmodernism and the Changing Intellectual Place of Archives," The American Archivist 65, no.1 (Spring / Summer 2002): 24-41. See for a similar approach my earlier article on the reiteration of archival footage on Dutch television: Andrea Meuzelaar, "From Single Male Guest Worker to Muslim. An Archaeology of Iterating Archival Footage on Dutch Television," NECSUS. European Journal of Media Studies 5, no. 2 (2016): 15-48.

17. Michel Foucault, "Politics and the Study of Discourse," in The Foucault Effect. Studies in Governmentality, eds. Graham Burchell and Colin Gordon (Chicago: University of Chicago Press, 1991), 59.

18. Michel Foucault, The Archaeology of Knowledge, trans. A.M. Sheridan Smith (London and New York: Routledge, 2006), $155-157$.

19. Ann Laura Stoler, Along the Archival Grain. Epistemic Anxieties and Colonial Common Sense (Princeton and Oxford: Princeton University Press, 2009); Stoler, "Colonial Archives and the Arts of Governance."

20. Stoler, "Colonial Archives and the Arts of Governance," 92 and 86.

21. Ibid., 98.

22. Derrida, Archive Fever, 36 and 18.

23. See for an overview of the institutional history of Sound and Vision: Irma van Kampen and Lisette Graswinckel, "Selection and Retention. A Shift of Focus from Collection to Catalogue," in Changing Sceneries, Changing Roles. Selected papers from the FIAT Media Management Seminar (Stockholm, 2009): 158-169.

24. Annemiek de Jong, "Users, Producers \& Other Tags. Trends and Developments in Metadata Creation," paper presented at the FIAT/IFTA Conference, Lisbon, October 14, 2007: 2.

25. Nesmith, "Seeing Archives," 33.

26. It was beyond the scope of my project to investigate how journalists have actually chosen to reappropriate archival footage and to explore all factors at play in television's canonisation of the same generic images (such as the speed of the production process, the lack of fantasy of journalists to think of alternative images to visualise their stories and other factors relating to 
money and technology). My focus is on the interplay between the compelling logic of the medium of television to constantly visualise abstract stories and the archiving practices of Sound and Vision that support this logic.

27. This research was part of my PhD project: Andrea Meuzelaar, "Seeing Through the Archival Prism. A History of the Representation of Muslims on Dutch Television," PhD Diss., (University of Amsterdam, 2014). In 2018, the iMMix catalogue (the Multimedia Asset Management System) was replaced by DAAN (Digitaal Audiovisueel Archief van Nederland).

28. I have chosen the year 1960 as a start, because it was the year that the first Islamic labour immigrants began to enter the Netherlands (first from Turkey and a few years later also from Morocco).

29. The patterns that I have identified are empirically grounded: I have based the analysis of the thematic structure and visual repertoires first and foremost on the viewing of the material. If material was not available - because of its carrier (in the early decades not all material that has been preserved on film has been migrated to video or digital formats), because it was missing, or because the large amount of hits made it impossible to view all material (in the case of the last two decades) - then I have based my findings on the descriptions of the material. For the identification of the thematic patterns of the television coverage, I have coded the material with themes that I have based on my own observations. Besides, I have looked at the additional keywords that have been added to the material by Sound and Vision, because these additional keywords give a clear indication of the thematic structure of the coverage. For the description of the visual repertoires (a term I use to refer to the core generic images that television has used to visualise stories about Muslim immigrants), I have viewed the material and I have identified patterns of recurring generic images.

30. Although Foucault's scope on discourse is very broad and covers the totality of discursive practices within a society and despite the fact that he does not give concrete suggestions for the analysis of empirical data, I suggest that his insights can be fruitfully employed to analyse archival and television discourse. To identify the four discursive formations, I have adhered to Foucault's methodology of archaeology, I have mapped the verbal traces left by history in the archive and in the broadcast material, and have considered these discursive evidence of (historically variable) dominant narratives of Muslim immigrants. I have identified moments of discontinuity in the discourse by analysing when and how the dominant keywords that Sound and Vision has used to label the broadcast material changed, when and how the language used by television shifted, and when and how new televisual narratives emerged. So the four discursive formations have emerged from the archive's system of classification and from my own coding of the broadcast material. See for a more detailed description of the method that I have used to identity these four discursive formations: Meuzelaar, Seeing through the Archival Prism, 67-79.

31. Although the Dutch already had come into contact with Islam as a result of their diplomatic and commercial involvement with the Ottoman Empire and their colonial rule in the Dutch East Indies, this contact was indirect and did not have any profound impact on the majority of Dutch society. And while the presence of Muslims in the Netherlands dates from before the Second World War, it was only during the post-war period that the scale of Islamic immigration began to increase rapidly. In the 1950's and early 1960's, small groups of Muslims entered the Netherlands; some were Indonesian and Moluccan Muslims who came as a result of the decolonization of Indonesia, while others were early immigrants from Surinam. However, the emergence of Islam in the Netherlands was - besides this colonial and postcolonial immigration and more recently the arrival of asylum seekers - most of all the result of labour immigration from Turkey and Morocco that began in the early 1960's and assumed vast proportions in the decades that followed. See for a more extensive overview of the history of Muslim presence in the Netherlands: Jan Rath, Rinus Penninx, Kees Groenendijk and Astrid Meyer, Western Europe and its Islam (Leiden, Boston and Köln: Brill, 2001).

32. Hans Vermeulen and Rinus Penninx, eds., Immigrant Integration. The Dutch case (Amsterdam: Het Spinhuis, 2000$), 6-7$.

33. Meuzelaar, "Seeing through the Archival Prism," 79-80. The archive has often used the word "guest workers" in its archival descriptions, but it has never been an official keyword.

34. Ibid., 79-82 and 86-92.

35. There is a lot more to say about the problematic and patronising aspects of this discourse of tolerance and hospitality and about the connotative presence of 'race' in television's coverage of foreign workers, but this is beyond the scope of this research that focusses particularly on the television's representation of their Islamic identity.

36. Ibid., 83-84 and 92-94.

37. Most of the current affairs items that addressed the religious identity of labour immigrants were broadcast by the religiously inspired broadcast organisations of the Dutch pillarized broadcasting system. These programs obviously spoke from a position that valued religion as an important part of one's identity and displayed an urgency to introduce the Dutch audience to this 'new' religion.

38. Kenmerk (IKOR, 16-01-1967).

39. Zienswijze (NOS, 23-11-1969), Journaal (NTS, 01-01-1968).

40. 'T Zand (RKK, 14-06-1979).

41. Van Gewest tot Gewest (NOS, 06-11-1974).

42. Wat gaat ons dat aan? (IKON, 05-11-1987).

43. Ander Nieuws (NCRV, 19-02-1978).

44. Van Gewest tot Gewest (NOS, 06-11-1974).

45. See for instance an item of Televizier (AVRO, 14-01-1965), that revolved around the remigration of a group of Turkish guest workers. The item did not mention their Islamic religion, but did contain a short scene of prayer, that was highlighted in the archival 
description ("a Turk praying on a mat"). See also an episode of Brandpunt (KRO, 27-11-1965), that addressed the poverty in Morocco that caused Moroccan men to immigrate to the Netherlands. The program did not mention their religious identity, but did show visuals of a prayer, that was highlighted in the archival description ("a group of Moroccans praying on the street").

46. Vermeulen \& Penninx, Immigrant Integration, 18-21. The formula "integration with the preservation of cultural identity" ("integratie met behoud van eigen identiteit") summarised the official policy concerning the position of ethnic minorities in society. The emancipation of these groups had to be supported by granting them the right to live according to their own cultural backgrounds. The policy was directed at a number of target groups that were considered to be in danger of becoming marginalised; among these were the former guest workers, Moluccans, Surinamese, Antilleans, refugees and asylum seekers. The goal was to realise equal participation in the areas of labour, education and housing.

47. Ibid., 7.

48. Since cultural background had now become a relevant factor in integration politics, the climate became favourable for the growth of Islamic organisations. Islamic immigrants started to make use of the Dutch system of pillarization and started to found mosques, Islamic schools and a Muslim Broadcasting service. See for more information: Jan Rath, Rinus Penninx, Kees Groendendijk and Astrid Meyer, Western Europe and its Islam (Leiden, Boston and Köln: Brill, 2001), 82-84.

49. Meuzelaar, "Seeing through the Archival Prism," 96.

50. Ibid., 96-100.

51. Malik, The Meaning of Race, 150.

52. Meuzelaar, "Seeing through the Archival Prism," 100-102.

53. Ibid., 102-103.

54. Ibid., 103-105. What has become known as the Rushdie affair was in fact a whole series of transnational events over an extended period of time that followed upon the publication of Salman Rushdie's novel The Satanic Verses in September 1988. Numerous Muslims worldwide considered the book offensive and blasphemous, and began to publicly express their anger and proclaim the death of the author. It started in the beginning of 1989 with book burnings, demonstrations and riots in India, the UK, and Pakistan. Then, in February, ayatollah Khomeini issued his fatwa on Rushdie, which stated that the author was an infidel and should be killed for insulting the Quran and the Prophet. In March, the grim atmosphere and sense of crisis reached the Netherlands, where various Dutch Muslims (mainly from a Pakistani background) demonstrated in the streets of The Hague and Rotterdam.

55. Balibar, "Is there a 'Neo-Racism'?," 18.

56. Cigdem Yuksel, "Moslima. Een Onderzoek naar de Representatie van Moslima's in de Beeldbank van het ANP" [Muslima. An Investigation of the Representation of Muslima's in the Image Archive of ANP], unpublished manuscript, October, 2002: http://cigdemyuksel.com/ (accessed November 9, 2020).

57. Journaal (NOS, 22-11-1984).

58. Tijdsein (EO, 08-01-1980).

59. Ander Nieuws (NCRV, 18-03-1984).

60. Televizier (AVRO, 07-03-1986).

61. De Islam (STV, 11-11-1987).

62. Baukje Prins, Voorbij de Onschuld. Het Debat over de Multiculturele Samenleving [Beyond Innocence. The Debate about the Multicultural Society] (Amsterdam: van Gennep, 2000).

63. The archive of Sound and Vision has never allowed the word "allochtonen" to be an official keyword, since it was considered stigmatising. However, in the extensive descriptions of the material the word was very often used.

64. Meuzelaar, "Seeing through the Archival Prism,"107-112.

65. Ibid., 112-116.

66. Ibid.

67. Bhabha, "The Other Question," 81.

68. These were not the exact same images that were used in the previous decades, but generic images that very much looked the same as the generic images that were used earlier. My main argument is that images of mosques and prayers are iterative in the sense that these are the kind of images that that television kept resorting to and obsessing over, even in stories that no longer had anything to do with the religious practices of Muslims.

69. Brandpunt (KRO, 10-05-1992).

70. Islam in Nederland (NOS, 07-11-1993).

71. Achter het Nieuws (VARA, 28-01-1992).

72. Nieuwe Buren (AVRO, 10-03-1994).

73. Politician and professor European studies Paul Scheffer published his essay "The Multicultural Drama" in the Dutch newspaper $N R C$, in which he declared the multicultural society bankrupt and stated that integration had failed.

74. Meuzelaar, "Seeing through the Archival Prism," 119

75. Ibid., 118-123.

76. Ibid., 123-135. 
A. Meuzelaar, Tracing the History of Representation of Muslim Immigrants along the Archival Grain

\section{Biography}

Andrea Meuzelaar is a lecturer at the Department Media and Culture Studies at Utrecht University. In October 2014 she received her PhD from the Amsterdam School of Cultural Analysis. Her PhD research, entitled Seeing through the Archival Prism. A History of the Representation of Muslims on Dutch Television, explores the history of Dutch television coverage of Muslims in the Netherlands, from the arrival of the first Islamic guest workers in the sixties until the recent era of the 2000's, in which Islam became a very contested and salient issue. 